\title{
ТРИ ГИПОТЕЗЫ МУЛЬТИКУЛЬТУРАЛИЗМА В ТРЕХ ДНЯХ: ОТОБРАЖЕНИЕ 46 ЭТНИЧЕСКИХ МЕНЫШИНСТВ РОССИЙСКИМИ ОНЛАЙН-СМИ
}

\author{
А.А. ХАПЦОВА ${ }^{a}$ М.В. КЛЯСС
}

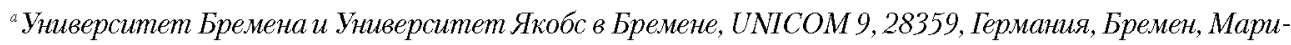
Зоммервилль-IIIтрассе 9

${ }^{\circ}$ IІКкола № 2114, 117216, Россия, Москва, Бульвар Дмитрия Донского, д. 14 А

'Национальный исследовательский утиверситет «Высиая икола экономики», 101000, Россия, Москва, ул. Мясниикая, д. 20

\begin{abstract}
Резюме
Тема мультикультурализма все больше привлекает внимание ученых, однако немного публикаций посвящено тому, как СМИ отображают это явление. Отображение межэтнических отношений СМИ - вопрос актуальный для России, где проживает более 160 этносов. В данном исследовании рассматривается, как российские онлайн-СМИ отображают 46 наиболее многочисленных проживающих в России этнических меньшинств с точки зрения трех гипотез межкультурного взаимодействия. В рамках исследования была разработана система индикаторов мультикультурализма для анализа медиасообщений. С помощью контент-анализа было установлено, что внимание онлайн-СМИ к разным аспектам мультикультурализма распределяется неравномерно. В частности, чаще всего меньшинства отображались с точки зрения гипотезы интеграции, реже всего - с позиции гипотезы контакта. Однако данное наблюдение несправедливо для отдельно взятых групп. Наиболее сбалансированно отображались проблемы алтайцев и грузин. В представлении остальных 44 групп СМИ делали акцент лишь на одном из трех аспектов мультикультурализма. Например, наиболее часто с точки зрения гипотезы интеграции представлялись лакцы и таджики; с точки зрения гипотезы идентичности - тувинцы, коми и чуваши; а с точки зрения гипотезы контакта - чеченцы и аварцы. Также было установлено, что, хотя в целом СМИ рассказывают об этнических менышинствах позитивно, эта тенденция не выдерживается в отношении отдельных групп: одни этносы представлялись исключителыно позитивно (тувинцы, лакцы, мордва), другие же - преимущественно негативно (узбеки, таджики, азербайджанцы). Потенциальные последствия такого неравномерного отображения этнокультурыых групп СМИ для восприятия этих групп представлены в обсуждениях результатов.
\end{abstract}

Ключевые слова: мультикультурализм, этнические меньшинства, онлайн-СМИ, контентанализ.

Исследование выполнено при поддержке гранта Российского научного фонда, проект № 15-18-00029. Во время планирования и проведения подготовительных этапов исследования все соавторы статьи являлись сотрудниками Международной научно-учебной лаборатории социокультурных исследований НИУ ВШЭ. 
Понимание мультикультурализма, а также его предпосылки и последствия область исследований разных направлений социальных наук. Интерес исследователей к проблемам мультикультурных обществ неуклонно растет: по данным Scopus, количество публикаций, посвященных этой теме, выросло с 1 в 1978 г. до 307 в 2016 г. Однако существующие исследования редко обращают внимание на то, как СМИ отображают мультикультурализм. В то же время СМИ являются важным источником информации о межкультурных отношениях для представителей всех этнокультурных групп, проживающих на территории страны. С одной стороны, информация, поступающая по каналам СМИ, может являться основой для стереотипов и предубеждений (Melican, Dixon, 2015), особенно в условиях ограниченных личных контактов с аут-группами (White yet al., 2012). С другой стороны, некоторые группы, в частности иммигранты, в значительной мере полагаются на СМИ как инструмент адаптации к новой культуре (Reесе, Palmgreen, 2000). Роль СМИ в межкультурных отношениях отражается в результатах европейского мониторинга обшественного мнения Eurobarometer № 63.3 (European Commission: Eurobarometer, 2006): значительная доля жителей 25 европейских стран (от 51 до 91\%, среднее - 78\%) считают, что СМИ играют важную роль в борьбе с дискриминацией.

То, как мультикультурализм отражается в СМИ, - вопрос актуальный для России, где проживает более 160 этнических групп (Всероссийская перепись населения, 2010). Одним из основных источников информации для россиян является Интернет (ВЦИОМ, 2015, 2016). Более половины населения России имеет свободный доступ к Интернету (Омнибус ГФК, 2015), и около 80\% пользователей время в сети посвящают чтению новостей (ФОМ, 2016). Воспринимаемая важность и доступность онлайн-СМИ делают изучение характера освещения мультикультурализма в массмедиа актуальным. В нашем исследовании мы будем опираться на концепцию Дж. Берри (Berry, 2015), согласно которой мультикультурализм невозможен без выполнения трех условий - так называемых трех гипотез межкультурного взаимодействия. Настоящее исследование - это первая попытка изучить, как онлайн-СМИ отображают этнические меньшинства России с точки зрения трех гипотез межкультурного взаимодействия.

\section{Понятие мультикультурализма и его изучение}

Прежде чем мы перейдем к обсуждению того, как изучать отображение мультикультурализма и межкультурных отношений в СМИ, следует сказать несколько слов о том, как это явление понимается в разных направлениях социальных исследований, и о том, какого подхода будем придерживаться мы. Понятие мультикультурализма имеет разные трактовки в зависимости от научной дисциплины, в фокус исследований которой оно попало. Дж. Берри, P. Калин и Д. Тейлор (Berry et al,, 1977) выделяют три подхода к пониманию того, что такое мультикультурализм: (1) в рамках первого подхода мультикультурализм понимается как культурное разнообразие состава населения; (2) в рамках второго подхода мультикультурализм рассматривается как идеология, которая поддерживает ценность культурного разнообразия для общества; (3) в 
рамках третьего подхода мультикультурализм - ряд политических мер, направленных на обеспечение взаимной адаптации различных этнокультурных групп, проживающих на одной территории, и их интеграцию в жизнь общества. Каждый из этих подходов имеет свои преимущества и недостатки. Например, использование первого подхода в исследованиях обеспечивает относительную простоту определения степени мультикультурности общества: чем больше культурное разнообразие, тем более мультикультурным является общество. Однако ограничение данного подхода заключается в том, что он не учитывает ни характера межкультурных отношений в обществе, ни наличия условий для интеграции различных групп (Bloemraad, 2011). Так, например, когда некоторые политики объявили «провал мультикультурализма» в Европе, ученые отметили, что с точки зрения второго и третьего подходов, в Европе никогда не было мультикультурализма (Bloemraad, Wright, 2014; Kalin, Berry, 1995). Мультикультурализм как идеология и политика направлен на интеграцию поликультурных обществ, улучшение межкультурных отношений, снижение дискриминации и повышение вовлеченности представителей разных этнокультурных групп в жизнь общества (Berry, 2015). Согласно Дж. Берри (Ibid.), в мультикультурной модели межкультурных отношений используется именно термин «этнокультурные группы», который подчеркивает, что статус этих групп (например, «большинство/меньшинство», «индигенные народы/иммигранты») не важен, интересы и потребности всех групп должны учитываться обществом. Преимуществом использования этих двух подходов является более глубокий и всесторонний анализ процессов, протекающих в обществе. Для того чтобы политика мультикультурализма была успешной, необходимо выполнение трех условий (Berry, Sam, 2014), которые получили название «трех гипотез межкультурного взаимодействия»:

1. Людям необходимо чувствовать, что их идентичности ничто не угрожает. Это позволяет им более толерантно относиться к представителям других этнокультурных групп (гипотеза мультикультурализма);

2. Участие представителей этнокультурных групп в общественной жизни как своего сообщества, так и в жизни общества в целом повышает их субъективное благополучие (zипотеза интеграции);

3. Для снижения взаимной предубежденности необходим контакт между представителями различных групп (zипотеза контакта).

Способствует ли выполнение этих трех условий взаимной адаптации представителей различных этнокультурных групп - проблема, которая изучается в разных странах (Dandy, Pe-Pua, 2010; Gui et al., 2016; Hui et al., 2015), включая Россию (Galyapina, Lebedeva, 2016; Lebedeva et al., 2016; Ryabichenko, Lebedeva, 2016). Все эти исследования выполнены в рамках проекта MIRIPS в котором мультикультурализм понимается как идеология, подразумевающая, что культурное разнообразие - это благо для общества в целом и для его

${ }^{1}$ MIRIPS - Mutual Intercultural relations in Plural Societies; описание проекта доступно по ссылKe: http://www.victoria.ac.nz/cacr/research/mirips/MIRIPSprojectdescription-August-2013.pdf 
отдельных членов. Вслед за этими исследованиями мы будем понимать мультикультурализм, в первую очередь, как мультикультурную идеологию.

Однако успех мультикультурной идеологии может зависеть не только от того, насколько широко она внедряется в повседневную жизнь людей, но и от того, как мультикультурализм отражают СМИ. Например, в таких странах, как Канада, Австралия и Финляндия, имеющих высокие показатели по индексу $\mathrm{MIPEX}^{2}$, СМИ склонны стереотипизировать представителей этнокультурных меньшинств и отображать население более гомогенным с точки зрения его этнического состава в сравнении с реальным положением дел (Pietikainen, Hujanen, 2003; Poindexter et al., 2003). Проблемы неадекватного отображения как отдельных этнокультурных групп, так и межкультурных отношений в целом могут привести к неверным представлениям о составе населения (Zhao, Postiglione, 2010), что, в свою очередь, может спровоцировать отторжение мультикультурализма и всех его проявлений. Однако попыток изучить отображение мультикультурализма в СМИ ранее не предпринимались. Наша статья посвящена изучению того, как онлайн-СМИ отображают межкультурное взаимодействие в России. В частности, мы предлагаем операционализацию трех гипотез межкультурного взаимодействия (Berry, 2015) через систему индикаторов этих гипотез в медиасообщениях, а также с помощью контент-анализа тестируем, как 46 наиболее многочисленных этнических меньшинств отображаются в онлайн-СМИ через призму гипотез межкультурного взаимодействия.

\section{Методы исследования}

\section{Вьюбока}

Чтобы проанализировать, как СМИ отображают наиболее многочисленные этнические меньшинства $(\mathrm{N}=46)$, проживающие на территории РФ (Всероссийская перепись населения, 2010), мы отобрали все сообщения, содержащие этнонимы, каждой из групп. Поиск сообщений осуществлялся через поисковую систему «Яндекс. Новости» - самый популярный сервис для поиска новостей в России (MediaScope, 2017). Отбор сообщений для анализа осуществлялся по четырем критериям: (1) события происходили на территории России; (2) сообщения описывают этнические группы и представителей этих групп, проживающих на территории РФ в настоящее время; (3) этнонимы были использованы для обозначения людей, принадлежащих к соответствующим этнокультурным группам, для обозначения самих групп или элементов культуры этих групп; (4) материалы были опубликованы между 28 и 30 июня

\footnotetext{
${ }^{2}$ MIPEX (Migrant International Policy Index) - индекс, оценивающий условия проживания и интеграции мигрантов в разных странах. На 2016 г. доступны данные для 38 стран, среди них Финляндия (4-е место), Канада (6-е место), Австралия (8-е место), которые попадают в категорию стран с наиболее благоприятными условиями для интеграции мигрантов (http://www.mipex.eu/key-findings).
} 
2017 г. Последнее условие позволяет воссоздать опыт пользователей поисковой системы, если бы они захотели ознакомиться с последними новостями, касающимися любой из этнокультурных групп. Выбор дат был случайным. Выборку составило 156 новостных сообщений. Поскольку в одном сообщении могли упоминаться разные аспекты мультикультурализма, а также сразу несколько групп, единицей анализа мы выбрали не сами сообщения, а тематические сегменты внутри сообщений, общее количество проанализированных сегментов составило 624.

Частота упоминаний этнокультурных групп в этих сообщениях, а также отношение частоты появлений групп в СМИ к доле, занимаемой популяцией этой группы среди других меньшинств, представлено в таблице 1. В выборке оказались непредставленными вовсе коми-пермяки, даргинцы, табасараны, лезгины и кумыки - относительно этих групп в онлайн-СМИ не было ни одного сообщения в период сбора данных. Избыточно представленными оказались карелы, таджики и хакасы.

Таблица 1

Частота упоминания основных 46 этнокультурных групा в онлайн-СМИ

\begin{tabular}{|l|c|c|c|c|c|}
\hline Этнокультурная группа & Сообщ. & Сообщ. (\%) & Сегм. & N (\%) & Отн. $^{* 1}$ \\
\hline Аварцы & 4 & 2.55 & 14 & 3.59 & 0.71 \\
\hline Адыгейцы & 4 & 2.55 & 15 & 0.49 & 5.17 \\
\hline Азербайджанцы & 10 & 6.37 & 16 & 2.38 & 2.68 \\
\hline Алтайцы & 3 & 1.91 & 7 & 0.29 & 6.51 \\
\hline Армяне & 17 & 10.83 & 41 & 4.66 & 2.32 \\
\hline Балкарцы & 1 & 0.64 & 16 & 0.45 & 1.43 \\
\hline Башкиры & 11 & 7.01 & 47 & 6.26 & 1.12 \\
\hline Белорусы & $\mathbf{6}$ & 3.82 & 10 & 2.06 & 1.86 \\
\hline Буряты & 8 & 5.10 & 31 & 1.82 & 2.80 \\
\hline Греки & 2 & 1.27 & 2 & 0.34 & 3.77 \\
\hline Грузины & 4 & 2.55 & 9 & 0.62 & 4.10 \\
\hline Даргинцы & 0 & 0 & 0 & 2.32 & 0.00 \\
\hline Евреи & 5 & 3.18 & 12 & 0.62 & 5.16 \\
\hline Ингушп & 5 & 3.18 & 6 & 1.75 & 1.82 \\
\hline Кабардинцы & 5 & 3.18 & 0 & 2.55 & 1.25 \\
\hline Казахи & 2 & 1.27 & 6 & 2.55 & 0.50 \\
\hline Калмыки & 1 & 0.64 & 4 & 0.72 & 0.88 \\
\hline Карачаевцы & 7 & 4.46 & 9 & 0.86 & 5.18 \\
\hline Карелы & 11 & 7.01 & 15 & 0.24 & 29.17 \\
\hline Киргизы & 0.64 & 14 & 0.41 & 1.57 \\
\hline
\end{tabular}


Таблица 1 (окончание)

\begin{tabular}{|l|c|c|c|c|c|}
\hline Этнокультуная группа & Сообщ. & Сообщ. (\%) & Сегм. & N (\%) & отн. \\
\hline Коми & 5 & 3.18 & 5 & 0.9 & 3.53 \\
\hline Коми-пермяки & 0 & 0 & 0 & 0.37 & 0.00 \\
\hline Корейцы & 1 & 0.64 & 8 & 0.6 & 1.05 \\
\hline Кумыки & 0 & 0 & 0 & 1.98 & 0.00 \\
\hline Лакцы & 2 & 1.27 & 8 & 0.7 & 1.81 \\
\hline Лезгины & 0 & 0 & 0 & 1.87 & 0.00 \\
\hline Марийцы & 10 & 6.37 & 3 & 2.16 & 2.94 \\
\hline Молдоване & 3 & 1.91 & 16 & 0.62 & 3.10 \\
\hline Мордва & 2 & 1.27 & 13 & 2.94 & 0.43 \\
\hline Немцы & 3 & 1.91 & 7 & 1.56 & 1.23 \\
\hline Ногайцы & 6 & 3.82 & 13 & 0.41 & 9.35 \\
\hline Осетины & 14 & 8.92 & 19 & 2.08 & 4.28 \\
\hline Табасараны & 0 & 0 & 0 & 0.58 & 0.00 \\
\hline Таджики & 14 & 8.92 & 17 & 0.79 & 11.32 \\
\hline Татары & 13 & 8.28 & 33 & 20.97 & 0.39 \\
\hline Тувинцы & 1 & 0.64 & 1 & 1.04 & 0.61 \\
\hline Турки & 1 & 0.64 & 1 & 0.41 & 1.54 \\
\hline Удмурты & 10 & 6.37 & 34 & 2.18 & 2.92 \\
\hline Узбеки & 14 & 8.92 & 28 & 1.14 & 7.82 \\
\hline Украинцы & 5 & 8.92 & 19 & 7.61 & 1.17 \\
\hline Хакасы & 3.82 & 19 & 0.29 & 13.25 \\
\hline Цыгане & 5.10 & 19 & 0.81 & 6.31 \\
\hline Черкесы & 10 & 6.37 & 19 & 5.65 & 1.13 \\
\hline Чеченцы & 1.27 & 21 & 5.67 & 0.22 \\
\hline Чуваши & 3.18 & 32 & 1.89 & 1.69 \\
\hline Якуты & & & & 6.62 \\
\hline
\end{tabular}

Примеиание. Сообщ. - количество сообщений, упоминающих групп; Сообщ. (\%) - количество сообщений, упоминающих группу (\%); Сегм. - количество проанализированных сегментов сообщений, содержащих этноним; N (\%) - численность группы среди основныт 46 этнокультурных меньшинств России (\%); Отн. - отношение доли упоминаний группы в выборке новостей к доле, занимаемой популяцией группы среди основных этнокультурных групп России.

* Значения, близкие к 1, обозначают, что частота упоминаний группы в выборке приблизительно пропорциональна доле, занимаемой популяцией этой группы среди основных этнических меньшинств России; значения < 1 обозначают, что группа была недостаточно представлена в СМИ; значения > 1 обозначают, что группа была избыточно представлена в СМИ. 


\section{Анализ}

Анализ освещения культурного разнообразия в новостях осуществлялся методом качественного контент-анализа. Гипотезы межкультурного взаимодействия сформулированы их автором в виде взаимоотношений между переменными (например, чем больше люди уверены в собственной идентичности, тем более они открыты к аут-группам). Однако в рамках исследований отдельных сообщений СМИ отследить взаимосвязи затруднительно, поэтому мы разработали систему индикаторов для каждой из гипотез межкультурного взаимодействия. Разработка индикаторов проводилась как дедуктивно, так и индуктивно: в частности, мы использовали формулировки «трех гипотез» для определения основных категорий анализа, в то время как специфические индикаторы были выведены индуктивно.

\section{Гипотеза мультикультурализма}

В поликультурных обществах для благополучного существования представителям всех групп необходимо чувствовать, что их идентичности ничто не угрожает (Berry, Sam, 2014) и что их этническая культура ценна для общества и принимается другими (Plaut et al., 2011). Индуктивно мы получили следующие индикаторы гипотезы идентичности:

1. Самоидентификация героя сообщения с какой-либо группой. Пример: «...а мы ведъ тоже адыги!» (советская-адыгея.рф)з.

2. Отсылки к культурно-историческому наследию группы (музеи этнической культуры, памятники видным представителям этноса, праздники, языки), если не упоминаются участники, чья этническая принадлежность известна. Пример: «В свою очередь, количество отказов от башкирского языка рискует стать лавинообразным» (proufu.ru).

3. Эмоциональные высказывания людей о своей этнической принадлежности. Пример: «Почему я люблю свою Бурятию? Да потому ито я родилась здесь. <..> И я горжусь тем, ито являюсь гражданином Бурятии!» (gumilevcenter.ru).

\section{Гипотеза интеграции}

Гипотеза интеграции предполагает, что представители этнокультурных групп, которые, с одной стороны, поддерживают культуру своего сообщества, а с другой стороны, принимают активное участие в жизни общества в целом, более успешно адаптируются в нем (Berry, 2015). Хотя данная гипотеза предполагает, что для успешной интеграции люди должны одновременно участвовать в жизни обоих сообществ, зафиксировать это в сообщениях СМИ затруднительно. Поэтому мы предлагаем две группы индикаторов гипотезы интеграции, которые отражают обе стороны гипотезы.

\footnotetext{
${ }^{3}$ Полные ссылки на источники цитат из примеров приведены в приложении.
} 
1. Вовлеченность в жизнь этнокультурного сообщества:

1.1. Общественная деятельность: участие в деятельности общественных организаций, целью которых является помощь членам ин-группы, сохранение культурного наследия и др. Пример: «Председатель учалинского Курултая баикир Зиля Рахматуллина» (gumilev-center.ru).

1.2. Традиционные практики:

1.2.1. Поведение, мотивированное нормами культуры. Пример: «Рузанна Туко подверглась критике за наруиение черкесских традииий» (kavkazuzel.eu).

1.2.2. Занятия традиционным для группы спортом. Пример: «B эmom paз было сложно, много сильных соперников приехало. Особенно якуты - родоначальники вида спорта» (ogirk.ru).

1.2.3. Занятия традиционными видами искусства. Пример: «Известный певеи, солист народной вокальной группь “Эрирей” Хабас Бечелов исполнил а капелла песню о родном крае <о Балкарии >» (kbpravda.ru).

1.2.4. Занятия традиционными видами трудовой деятельности. Пример: «В наием городе живет старая цьганка-ведунья Лила» (abakan-news.ru).

1.3. Участие в праздниках и обрядах, традиционных для группы, проходящих исключительно с участием членов этой группы. Пример: «Удмурты приняли самое активное участие.. в национальном празднике “Тырон Быдтон”» (bavly-tat.ru).

1.4. Популяризация своей этнокультурной группы для членов ин-группы. Пример: «Проведение әтнокультурных лагерей для детей из числа российских немцев Центрального и Северо-Западного регионов России» (gov.cap.ru).

1.5. Использование этнического языка. Пример: «В Чувашии сейчас насиитыьвается около 13 тысяи человек мордовской национальности, которые, конечно же, испытывают потребность в общении на языке своего народа...» (info-rm.com).

1.6. Другое.

2. Участие в жизни общества в целом:

2.1. Общественная деятельность: представители этнокультурных групп, занимающиеся различными видами общественной деятельности, не связанной с их группой. Пример: «Сайгидуусейн Магомедов (авареи) является неоднократным претендентом на пост главы республики» (riaderbent.ru).

2.2. Трудоустройство/образование: представители этнокультурных групп, занимающиеся неспецифичным для их группы трудом, а также обучающиеся. Пример: «Командир атомной подводной лодки, капитан первого ранга в отставке, а ньне - поэт, а пакже уиитель истории, ветеран Афганистана, узбек Анвар Канантаров» (in-reutov.ru).

2.3. Искусство: представители этнокультурных групп, занимающиеся искусством или организацией публичных мероприятий, не связанных с их группой. Пример: «...театр под руководством Армена Джигарханяна...» (dni.ru).

2.4. Спорт: представители этнокультурных групп, занимающиеся спортом, нетрадиционным для их группы. Пример: «...ингуи Муса Евлоев... Сuитается, 
ито лииь травма не позволила этому бориу завоевать путевку на Олимпиаду$2016<$ <реко-римская борьба>» (ulpressa.ru).

2.5. Популяризация своей этнокультурной группы для широкой аудитории. Пример: «С 30 июня по 2 июля 2017 года в Республике Башкортостан будет проходить Открытый межнациональный форум "Баикирская молодежь приглаииает друзей” (samddn.ru).

2.6. Проведение этнокультурных праздников с участием представителей разных этнических групп. Пример: «На Советской площади торжествовал “хоровод культур": ярмарка народных ремесел, фестиваль ансамблей и начиональной кухни» (vsar.ru).

2.7. Другое.

Чтобы установить, сбалансированно ли СМИ отображают вовлеченность групп в жизнь своего сообщества и жизнь общества в целом, мы вычислили пропорцию упоминаний обоих типов вовлеченности. Значения, близкие к 1 , обозначают сбалансированное участие в жизни как своего сообщества, так и всего общества в целом, что в терминологии аккультурационных стратегий Берри (2015) соответствует интеграции. Значения > 1 - преимущественное участие в жизни этнокультурного сообщества (стратегия сепарации); значения $<1$ - преимущественное участие в жизни общества в целом (стратегия ассимиляции).

\section{Гипотеза контакта}

Гипотеза межгруппового взаимодействия (Pettigrew, Tropp, 2006) предполагает, что контакт с представителями аут-групп лежит в основе позитивных установок по отношению к представителям этих групп. Однако не только личные контакты способствуют улучшению взаимных установок. Результаты прошлых исследований показали, что простое наблюдение за межкультурным взаимодействием в повседневной жизни и в СМИ имеет сходный эффект (Lienemann, Stopp, 2013). Роль наблюдения за межкультурными контактами в СМИ особенно заметна, когда возможности личных контактов ограничены (White et al., 2012).

Для нашего исследования мы выделили три типа межэтнических контактов, упомянутых в СМИ:

1. Контакт на индивидуальном уровне, в котором участвуют конкретные индивиды или группы конкретных людей. Пример: «Я пошел к своим друзьямхакасам...» (gazeta19.ru).

2. Контакт на уровне индивид - группа. Пример: «...нецензурной беседой Александра Бердникова, которую некоторые интерпретировали как неуважение к титульной нации Республики Алтай» (bankfax.ru).

3. Контакт на групповом уровне, в котором участвуют абстрактные группы. Пример: «Ногайцы и иечениь живут вместе уже достаточно давно, и между народами крепкие дружеские отношения...» (chechnyatoday.com). 
Мы считали контакт межэтническим, если этнокультурная принадлежность хотя бы одной из сторон была указана в тексте.

Таким образом, на основании результатов исследований межкультурных отношений и отображения этих отношений в СМИ нами были выделены три группы индикаторов мультикультурализма в СМИ, соответствующие гипотезам межкультурного взаимодействия.

\section{Валентность новостных сообщений}

Идеология мультикультурализма предполагает, что культурное разнообразие - это благо для общества (Berry, 2015). Следовательно, представление культурного разнообразия в СМИ в позитивном ключе, вероятно, будет вести к принятию этой идеологии обществом. Например, гипотеза контакта предполагает, что контакт между представителями разных этнических групп позитивен (например, дружба или вступление в брак). Таким образом, отображение позитивных контактов СМИ также способствует развитию мультикультурализма. Однако не все сообщения в СМИ посвящены исключительно позитивным контактам: СМИ также освещают межэтнические конфликты и столкновения людей в повседневной жизни. Отображение исключительно негативных контактов, вероятно, будет способствовать отторжению идей мультикультурализма аудиторией и формировать представление о культурном разнообразии как угрозе. Чтобы определить, как СМИ представляют каждую из исследуемых этнокультурных групп в контексте гипотез межкультурного взаимодействия, мы оценивали валентность анализируемых сегментов сообщений. При этом под валентностью мы понимаем не эмоциональную оценку сообщений, а рассматриваем описанные события с точки зрения их вклада в представление мультикультурализма как позитивного явления. Например, приведенный выше пример индикатора гипотезы идентичности: «B свою очередь, количество отказов от баикирского языка <как икольного предмета> рискует стать лавинообразньм» (proufu.ru) - указывает на отвержение этого компонента идентичности башкир. Противоположный, позитивный пример поддерживает важность идентичности: «К съемкам короткометражного художественного фильма “Аман” на ногайском язике приступят в сентябре» (nazaccent.ru).

\section{Результаты}

Для того чтобы определить, с одинаковой ли частотой онлайн-СМИ отображали гипотезы межкультурного взаимодействия, мы вычислили доли упоминания каждой из гипотез от общего числа упоминания индикаторов гипотез в выборке. Мы определили, что чаще всего СМИ упоминали индикаторы двух компонентов гипотезы интеграции (55\% сегментов). Следующей по частоте упоминания оказалась гипотеза идентичности (30.90\% сегментов). Реже всего в СМИ упоминались межэтнические контакты (14.05\% сегментов). Мы определили, что такое распределение внимания СМИ к разным 
аспектам мультикульурализма статистически значимо отличается от равномерного $\left(\chi^{2}=98.01, p<0.01\right)$.

Такое распределение частоты появлений индикаторов в СМИ по выборке в целом не означает, что отдельные группы будут представлены аналогичным образом. Чтобы это проверить, мы провели аналогичный анализ для каждой из 41 группы. С помощью критерия $\chi^{2}$, мы определили, что наиболее равномерно индикаторы трех гипотез межкультурного взаимодействия СМИ встречались в отображении алтайцев $\left(\chi^{2}=4.08, p>0.05\right)$ и грузин $\left(\chi^{2}=0, p>0.05\right)$. Однако в отображении большинства групп СМИ выделяли лишь одну из сторон межкультурного взаимодействия. Чаще всего с точки зрения участия в общественной жизни (как общества в целом, так и своего этнического сообщества) СМИ освещали греков $\left(\chi^{2}=200, p<0.01\right)$, лакцев $\left(\chi^{2}=200, p<0.01\right)$ и таджиков $\left(\chi^{2}=166.78, p<0.01\right)$. С позиции идентичности СМИ в основном рассказывали о тувинцах $\left(\chi^{2}=200, p<0.01\right)$, коми $\left(\chi^{2}=104, p<0.01\right)$ и чувашах $\left(\chi^{2}=66.67, p<0.01\right)$. В контексте контактов чаще всего упоминались турки $\left(\chi^{2}=200, p<0.01\right)$, чеченцы $\left(\chi^{2}=50.42, p<0.01\right)$ и аварцы $\left(\chi^{2}=50, p<0.01\right)$.

Для того чтобы определить, одинаково ли часто, по версии СМИ, представители меньшинств принимают участие в жизни общества в целом и в жизни своего этнического сообщества, мы вычислили соотношение процента упоминаний обоих типов вовлеченности. Наиболее интегрированными оказались удмурты, татары, калмыки, ингуши, ногайцы и алтайцы - сообщения об участии әтих групп как в жизни общества в целом, так и в жизни әтнического сообщества появлялись с одинаковой частотой. Наиболее ассимилированными группами оказались марийцы, грузины, карачаевцы, молдаване и казахи в СМИ не было ни одного упоминания участия представителей этих групп в жизни своего сообщества. Наиболее сепарированными, как это могло показаться читателям, оказались коми, чуваши и немцы - СМИ не упоминали того, что представители этих групп принимают участие в жизни общества в целом.

Следующим шагом мы протестировали, с одинаковой ли частотой СМИ представляли позитивные, амбивалентные и негативные сообщения об этнических меньшинствах. В целом этнические меньшинства представлялись скорее позитивно (67.6\% сегментов). Амбивалентных и негативных сегментов было гораздо меньше (10.6 и 21.7\% сегментов соответственно). С помощью критерия $\chi^{2}$ мы обнаружили, что такое распределение валентностей не является сбалансированным $\left(\chi^{2}=98.01, p<0.01\right)$.

Чтобы проверить, сохраняется ли такое распределение для каждой из групп в отдельности, мы провели аналогичный анализ по группам. Ни одна из групп не отображалась СМИ сбалансированно с точки зрения валентности сообщений. Исключительно позитивно отображались тувинцы, турки, немцы, якуты, лакцы, ингуши, греки и мордва $\left(\chi^{2}=200, p<0.01\right.$ для всех групп). Наиболее негативно СМИ изображали узбеков $\left(\chi^{2}=66.67, \mathrm{p}<0.01\right)$, молдаван $\left(\chi^{2}=62.24, p<0.01\right)$, азербайджанцев $\left(\chi^{2}=56, p<0.01\right)$ и таджиков $\left(\chi^{2}=56\right.$, $p<0.01)$. 
Таблица 2

Равномерность появления индикаторов трех гипотез межкультурного взаимодействия и валентность онлайн-сообщений

\begin{tabular}{|c|c|c|c|c|c|c|c|c|c|}
\hline $\begin{array}{c}\text { Этническая } \\
\text { группа }\end{array}$ & $\begin{array}{l}\text { Идентич- } \\
\text { ность (\%) }\end{array}$ & $\begin{array}{c}\text { Контакт } \\
(\%)\end{array}$ & $\begin{array}{l}\text { Вовлечен- } \\
\text { ность (\%) }\end{array}$ & $x^{2}$ & $\begin{array}{c}\text { Стратегия } \\
\text { аккульту- } \\
\text { рации }\end{array}$ & $\begin{array}{c}\text { Негативные } \\
\text { сегменты } \\
(\%)\end{array}$ & $\begin{array}{c}\text { Амбивалент- } \\
\text { ные сегменты } \\
(\%)\end{array}$ & $\begin{array}{c}\text { Позитивные } \\
\text { сегменты } \\
(\%) \\
\end{array}$ & $x^{2}$ \\
\hline Аварцы & 0.00 & 50.00 & 50.00 & $50.00^{* *}$ & 0.40 & 42.86 & 14.29 & 42.86 & $16.33^{* *}$ \\
\hline Адыгейцы & 40.00 & 0.00 & 60.00 & $56.00^{* *}$ & 3.50 & 26.67 & 0.00 & 73.33 & $82.67^{* *}$ \\
\hline Азербайджанцы & 0.00 & 6.25 & 93.75 & $164.84^{* *}$ & 0.36 & 60.00 & 0.00 & 40.00 & $56.00^{* *}$ \\
\hline Алтайцы & 28.57 & 42.86 & 28.57 & 4.08 & 1.00 & 33.33 & 50.00 & 16.67 & $16.67^{* *}$ \\
\hline Армяне & 21.95 & 19.51 & 58.54 & $28.67^{* *}$ & 0.50 & 20.59 & 11.76 & 67.65 & $54.15^{* *}$ \\
\hline Балкарцы & 43.75 & 6.25 & 50.00 & $33.59^{* * *}$ & 7.00 & 7.69 & 0.00 & 92.31 & $157.40^{* *}$ \\
\hline Башкиры & 46.81 & 4.26 & 48.94 & $38.12^{* *}$ & 3.60 & 14.29 & 19.05 & 66.67 & $50.34^{* *}$ \\
\hline Белорусы & 10.00 & 10.00 & 80.00 & $98.00^{* *}$ & 0.14 & 50.00 & 0.00 & 50.00 & $50.00^{* *}$ \\
\hline Буряты & 58.06 & 3.23 & 38.71 & $46.41 * *$ & 0.50 & 3.45 & 6.90 & 89.66 & $142.93^{* *}$ \\
\hline Греки & 0.00 & 0.00 & 100.00 & $200.00^{* *}$ & 1.00 & 0.00 & 0.00 & 100.00 & $200.00^{* *}$ \\
\hline Грузины & 33.33 & 33.33 & 33.33 & 0.00 & 0.00 & 11.11 & 0.00 & 88.89 & $140.74^{* *}$ \\
\hline Даргинцы & - & - & - & - & - & - & - & - & - \\
\hline Евреи & 0.00 & 25.00 & 75.00 & $87.50^{* *}$ & 0.13 & 22.22 & 22.22 & 55.56 & $22.22^{* *}$ \\
\hline Ингуши & 33.33 & 0.00 & 66.67 & $66.67^{* *}$ & 1.00 & 0.00 & 0.00 & 100.00 & $200.00 * *$ \\
\hline Кабардинцы & - & - & - & - & - & - & - & - & - \\
\hline Казахи & 0.00 & 33.33 & 66.67 & $66.67^{* *}$ & 0.00 & 33.33 & 0.00 & 66.67 & $66.67^{* *}$ \\
\hline
\end{tabular}




\begin{tabular}{|c|c|c|c|c|c|c|c|c|c|}
\hline $\begin{array}{c}\text { Әтническая } \\
\text { группа }\end{array}$ & $\begin{array}{l}\text { Идентич- } \\
\text { ность (\%) }\end{array}$ & $\begin{array}{c}\text { Контакт } \\
(\%)\end{array}$ & $\begin{array}{l}\text { Вовлечен- } \\
\text { ность (\%) }\end{array}$ & $\chi^{2}$ & $\begin{array}{c}\text { Стратегия } \\
\text { аккульту- } \\
\text { рации }\end{array}$ & $\begin{array}{c}\text { Негативные } \\
\text { сегменты } \\
(\%)\end{array}$ & $\begin{array}{c}\text { Амбивалент- } \\
\text { ные сегменты } \\
(\%)\end{array}$ & \begin{tabular}{|c|} 
Позитивные \\
сегменты \\
$(\%)$
\end{tabular} & $\chi^{2}$ \\
\hline Калмыки & 50.00 & 0.00 & 50.00 & $50.00^{* *}$ & 1.00 & 25.00 & 0.00 & 75.00 & $87.50^{* *}$ \\
\hline Карачаевцы & 22.22 & 11.11 & 66.67 & $51.85^{* *}$ & 0.00 & 22.22 & 22.22 & 55.56 & $22.22^{* *}$ \\
\hline Карелы & 66.67 & 0.00 & 33.33 & $66.67^{* *}$ & 0.67 & 0.00 & 13.33 & 86.67 & $130.67^{* *}$ \\
\hline Киргизы & 7.14 & 7.14 & 85.71 & $123.47^{* *}$ & 0.09 & 28.57 & 7.14 & 64.29 & $50.00^{* *}$ \\
\hline Коми & 80.00 & 20.00 & 0.00 & $104.00^{* *}$ & - & 40.00 & 20.00 & 40.00 & $8.00^{* *}$ \\
\hline Коми-пермяки & - & - & - & - & - & - & - & - & - \\
\hline Корейцы & 12.50 & 12.50 & 75.00 & $78.13^{* *}$ & 0.50 & 0.00 & 16.67 & 83.33 & $116.67^{* *}$ \\
\hline Лакцы & 0.00 & 0.00 & 100.00 & $200.00^{* *}$ & 1.67 & 0.00 & 0.00 & 100.00 & $200.00^{* *}$ \\
\hline Марийцы & 66.67 & 0.00 & 33.33 & $66.67^{* *}$ & 0.00 & 0.00 & 50.00 & 50.00 & $50.00^{* *}$ \\
\hline Молдаване & 0.00 & 18.75 & 81.25 & $108.59 * *$ & 0.00 & 64.29 & 0.00 & 35.71 & $62.24^{* *}$ \\
\hline Мордва & 46.15 & 0.00 & 53.85 & $50.89^{* *}$ & 0.75 & 0.00 & 0.00 & 100.00 & $200.00^{* *}$ \\
\hline Немцы & 57.14 & 0.00 & 42.86 & $53.06^{* *}$ & - & 0.00 & 0.00 & 100.00 & $200.00^{* *}$ \\
\hline Ногайщы & 30.77 & 7.69 & 61.54 & $43.79^{* *}$ & 1.00 & 0.00 & 8.33 & 91.67 & $154.17^{* *}$ \\
\hline Осетины & 42.11 & 0.00 & 57.89 & $53.74^{* *}$ & 1.75 & 0.00 & 5.56 & 94.44 & $168.52^{* *}$ \\
\hline Табасараны & - & - & - & - & - & - & - & - & - \\
\hline Таджики & 0.00 & 5.88 & 94.12 & $166.78^{* *}$ & 0.23 & 60.00 & 0.00 & 40.00 & $56.00 * *$ \\
\hline
\end{tabular}




\begin{tabular}{|c|c|c|c|c|c|c|c|c|c|}
\hline $\begin{array}{c}\text { Әтническая } \\
\text { групाа }\end{array}$ & $\begin{array}{c}\text { Идентич- } \\
\text { ность (\%) }\end{array}$ & $\begin{array}{c}\text { Контакт } \\
(\%)\end{array}$ & $\begin{array}{l}\text { Вовлечен- } \\
\text { ность (\%) }\end{array}$ & $x^{2}$ & $\begin{array}{c}\text { Стратегия } \\
\text { аккульту- } \\
\text { рации }\end{array}$ & $\begin{array}{c}\text { Негативные } \\
\text { сегменты } \\
(\%)\end{array}$ & $\begin{array}{c}\text { Амбивалент- } \\
\text { ные сегменты } \\
(\%)\end{array}$ & $\begin{array}{c}\text { Позитивные } \\
\text { сегменты } \\
(\%)\end{array}$ & $x^{2}$ \\
\hline Татары & 54.55 & 15.15 & 30.30 & $23.69 * *$ & 1.00 & 14.71 & 32.35 & 52.94 & $21.97 * *$ \\
\hline Тувинцы & 100.00 & 0.00 & 0.00 & $200.00 * *$ & - & 0.00 & 0.00 & 100.00 & $200.00^{* *}$ \\
\hline Турки & 0.00 & 100.00 & 0.00 & $200.00^{* *}$ & - & 0.00 & 0.00 & 100.00 & $200.00^{* *}$ \\
\hline Удмурты & 67.65 & 2.94 & 29.41 & $63.49^{* *}$ & 1.00 & 3.13 & 0.00 & 96.88 & $181.84^{* *}$ \\
\hline Узбеки & 3.57 & 28.57 & 67.86 & $63.01^{* *}$ & 0.36 & 66.67 & 0.00 & 33.33 & $66.67^{* *}$ \\
\hline Украинцы & 5.26 & 10.53 & 84.21 & $116.90^{* *}$ & 0.07 & 50.00 & 0.00 & 50.00 & $50.00 * *$ \\
\hline Хакасы & 68.42 & 5.26 & 26.32 & $62.05^{* *}$ & 4.00 & 5.26 & 5.26 & 89.47 & $141.83^{* *}$ \\
\hline Цыгане & 10.53 & 10.53 & 78.95 & $93.63 * *$ & 0.67 & 35.29 & 17.65 & 47.06 & $13.15^{* *}$ \\
\hline Чеченцы & 0.00 & 52.63 & 47.37 & $50.42^{* *}$ & 1.25 & 55.56 & 5.56 & 38.89 & $38.89^{* *}$ \\
\hline Чуваши & 71.43 & 19.05 & 9.52 & $66.67 * *$ & - & 30.00 & 45.00 & 25.00 & $6.50^{*}$ \\
\hline Якуты & 34.38 & 0.00 & 65.63 & $64.65^{* *}$ & 4.25 & 0.00 & 0.00 & 100.00 & $200.00^{* *}$ \\
\hline
\end{tabular}

${ }^{*} p<0.05,{ }^{* * *} p<0.01,{ }^{* * *} p<0.001$

Стратегия аккультурации: 1 - интеграция, $<1$ - ассимиляция , > 1 - сепарация. 


\section{Обсуждение результатов и заключение}

Результаты эмпирического исследования показали, что индикаторы трех гипотез межкультурного взаимодействия появлялись в онлайн-СМИ не с одинаковой частотой. Больше всего внимания СМИ уделяли индикаторам гипотезы интеграции - тому, как представители этнокультурных меньшинств России принимают участие в жизни общества в целом и в деятельности различных этнокультурных сообществ. Реже всего СМИ освещали межэтнические контакты. Такое распределение внимания СМИ к различным аспектам мультикультурализма не сохранялось для отдельно взятых групп.

С позиции гипотезы идентичности интерес для СМИ представляли коми, чуваши, тувинцы, хакасы, удмурты, карелы и марийцы. В освещении этих групп СМИ обсуждали или подтверждали ценность их культурного наследия для общества. В противовес этому в СМИ за период сбора данных не встретилось ни одного сообщения с упоминанием индикаторов этнической идентичности аварцев, азербайджанцев, лакцев, греков, таджиков, молдаван, евреев, турков и чеченцев. $У$ читателей могло сложиться впечатление, что данные группы не имеют самобытной культуры или что эта культура имеет низкую ценность для общества. Любопытно, что с точки зрения ценности сохранения культурной идентичности освещались индигенные народы России, в то время как вопросы идентичности иммигрировавших народов и народов Кавказа замалчивались СМИ.

Сходный дисбаланс наблюдался и в освещении этнокультурных меньшинств с позиции гипотезы контакта. С одной стороны, турки, чеченцы и аварцы были в основном представлены как непосредственные участники межэтнических контактов. Причем чеченцы и аварцы контактировали в проанализированных сообшениях в основном друг с другом. С другой стороны, представители 13 из 46 этнических меньшинств оказались изолированными от других групп в освещении СМИ. Таким образом, у читателей могло сложиться впечатление, что хоть этнические меньшинства и населяют Россию, взаимодействие с ними в повседневной жизни маловероятно. Редкие упоминания межэтнических контактов в СМИ, по мнению Линманн и Стопп (Lienemann, Stopp, 2013), не способ́ствуют интересу людей к установлению контактов с представителями разных этнических групп в реальной жизни. Это, в свою очередь, может препятствовать развитию взаимных позитивных установок (Pettigrew, Tropp, 2006).

С точки зрения гипотезы интеграции наиболее часто в онлайн-СМИ упоминались лакцы, таджики, азербайджанцы и черкесы. При анализе соотношения вовлеченности представителей этих групп в жизнь этнического сообщества и в жизнь общества в целом обнаружилось, что черкесы и лакцы представлялись скорее сепарированными - занятыми в большей степени делами своего сообщества, а таджики и азербайджанцы были представлены как группы ассимилировавшиеся. Были также и группы, чья вовлеченность в общественную жизнь не была представлена вовсе, - коми и тувинцы. Они упоминались СМИ скорее как абстрактные группы, пассивные и не имеющие 
конкретных представителей. Важно отметить, что такое отображение СМИ степени интегрированности разных групп может существенно отличаться от реального положения дел. Это, в свою очередь, может развивать у читателей неверные представления о роли разных групп в жизни общества.

Таким образом, наше исследование обнаружило неравномерное отображение трех гипотез межкультурного взаимодействия в СМИ. Эти результаты сложно интерпретировать однозначно. С одной стороны, СМИ могут отображать межкультурное взаимодействие неполно или неточно. С другой стороны, СМИ призваны отображать реальность такой, какая она есть, и в этом случае обнаруженный нами паттерн взаимоотношений между группами далек от теоретической модели мультикультурализма, предложенной Дж. Берри (2015). Напомним, что в соответствии с этой моделью для успешного осуществления мультикультурной политики необходимо выполнение всех трех условий в отношении каждой этнокультурной группы, проживающей на территории страны. Однако для того чтобы установить, соответствует ли обнаруженное в этом исследовании отображение мультикультурализма реальности, необходимо сопоставление результатов исследований СМИ с результатами исследований непосредственных представителей этнических групп.

Мы вычислили, что в основном СМИ освещают события, связанные с представителями этнических меньшинств преимущественно позитивно. Таким образом, в онлайн-новостях культурное разнообразие в общем преподносилось скорее как благо.

Эта тенденция, однако, не сохраняется, если рассматривать каждую из групп в отдельности. Исключительно позитивно были представлены турки, греки, ингуши, лакцы, мордва, немцы, тувинцы и якуты.

Преимущественно негативно представлялись азербайджанцы, таджики, узбеки и молдаване, не являющиеся индигенными этносами России. Эти же группы избыточно упоминаются в СМИ. Как следствие, у читателей могло сложиться впечатление, что представителей этих групп гораздо больше, чем их на самом деле проживает в России. Негативность оценки и избыточность новостей может отрицательно влиять на отношение читателей к представителям этих групп в реальности (Melican, Dixon, 2015). С другой стороны, превалирование негативных сообщений может также отображать особенность рынка новостей. По замечанию Сорока (Soroka, 2004), СМИ более интенсивно откликаются на негативные происшествия, следуя за интересом потребителей к негативным сообщениям. Несмотря на то что в целом позитивные сообщения преобладали, несбалансированное с точки зрения валентности отображение событий потенциально может вести к поляризации взглядов аудитории на мультикультурализм (Stroud, 2010), а также к поляризации самих источников информации (Mullainathan, Shleifer, 2005).

Несбалансированность освещения событий СМИ с точки зрения валентности сообщений может способствовать распространению нереалистичных мнений о представителях разных этнокультурных групп. Например, позитивные/негативные сообщения о группах, в отношении которых позитивные/негативные стереотипы уже распространены в обществе, будут их только усиливать. 
Этот эффект протестировали А. Гиллерт, Г. Джейкоб́с и С. Мюллер (Hillert et al., 2014) на примере влияния освещения СМИ результатов биржевых торгов на стоимость акций компаний. Они обнаружили, что позитивные сообщения способствовали интенсивному росту стоимости акций, если она уже росла на момент появления сообщений, в то время как негативные сообщения ускоряли падение стоимости акций, уже начавших терять в стоимости. Обратного же әффекта обнаружено не было.

Несбалансированное отображение культурного разнообразия (как блага и как угрозы) может привести к тому, что аудитория, поддерживающая превалирующую в излюбленном источнике новостей точку зрения, будет игнорировать альтернативные точки зрения. Вероятно, оптимальным вариантом будет равномерное отображение положительных, амбивалентных и негативных сообщений. Такое отображение скорее поможет уменьшить поляризацию взглядов аудитории и постепенно сформировать позитивное отношение к культурному разнообразию.

\section{Литература}

Всероссийская перепись населения. (2010). Том 4. Режим доступа: http://www.gks.ru/free_doc/ new_site/perepis2010/croc/Documents/Vol4/pub-04-06.pdf

ВцИОМ. (2016, май). Пресс-выпуск № 3098. Режим доступа: http://wciom.ru/ index.php?id=236\&uid $=115679$

ВЦИОМ. (2015, май). Пресс-выпуск № 2829. Режим доступа: http://wciom.ru/ index.php?id=236\&uid $=115248$

Медиаскоп. (2017). WEB-Index: Аудитория интернет-проектов. Результаты исследования: Июнь 2017, Россия 0+. Режим доступа: http://mediascope.net/services/media/media$\begin{array}{llllllll}\text { a } & \mathbf{u} & \mathrm{d} & \mathrm{i} & \mathrm{e} & \mathrm{n} & \mathrm{c} & \mathrm{e}\end{array}$ internet/information/?arrFilter_pf\%5BYEAR $\% 5 \mathrm{D}=2017$ \&captcha_code $=0 \mathrm{c} 1 \mathrm{c} 60553 \mathrm{bee} 8 \mathrm{dd} 3 \mathrm{c} 8$ a591c9fb094ceb\&captcha_word $=44$ h38\&set_filter $=Y$

Омнибус GfK. (2016, январь). Проникновение интернета в России: итоги 2015 года. Режим доступа: https://www.gfk.com/fileadmin/user_upload/dyna_content/RU/Documents/ Press_Releases/2016/Internet_Usage_Russia_2015.pdf

ФОМ. (2016). Новости в интернете: Опрос интернет-пользователей о том, где они читают новости и какой информацией интересуются. Режим доступа: http://fom.ru/SMI-i-internet/12491

Ссылки на зарубежные источники см. в разделе References после аналоязыиного блока.

Приложение

Полные ссылки на источники примеров индикаторов гипотез межкультурного взаимодействия, использованных в статье

1. «B свою очередъ, количество отказов от баикирского языка рискует стать лавинообразным» (https://proufu.ru/news/society/molchanie_yagnyat_ili_chem_zakonchatsya_goryachie_spory_vokrug_bashkirskogo_yazyka/). 
2. «Почему я люблю свою Бурятию? Да потому ито я родилась здесь. <..> И я горжусь тем, ито являюсь гражданином Бурятии!» (http://www.gumilev-center.ru/aleksejj-cydenov-nagradil-finalistov-pervogo-konkursa-ehsse-ya-gorzhus-buryatiejj/).

3. «...а жы ведь тоже адыси!» (http://xn--7sbbfifdf3bzb6adm6k7bg.xnp1ai/index.php/obshchestvo/11927-pishchevaya-promyshlennost-adygei-v-god-vypuskaetporyadka-10-tys-tonn-samogo-autentichnogo-produkta-no-zhitelyam-rossii-ego-nedostaet)

4. «Я пошел к своим друзьям-хакасам...» (http://gazeta19.ru/news/59101).

5. «... с неиензурной беседой Александра Бердникова, которую некоторые интерпретировали как неуважение к титульной нации Республики Алтай» (https://www.bankfax.ru/news/105967/).

6. «Ногайцы и чеченцы живт вместе уже достатоино давно, и между народами крепкие дружеские отноиения» (https:/chechnyatoday.com/content/view/303267).

7. «В Чуваиии сейчас насчитывается около 13 тысяи человек мордовской национальности, которые, конеино же, испытывают потребность в общении на языке своего наро$\partial a \gg$ (http://info-rm.com/2017/06/28/delegaciya_nordovii_prinyala_uchastie_v_prazdnovanii_dnya_respubliki_v_chuvashii.html/).

8. «Удурты приняли самое активное уиастие ... в национальном празднике "Гырон Бъљтон” (http://www.bavly-tat.ru/component/k2/item/17962-bavlinskie-udmurtyiprinyali-uchastie-v-pervom-molodyozhnom-forume-bigerd.html).

9. «B наием городе живет старая цыцанка-ведунъя Лила» (http://abakannews.ru/2017/06/28/\%D1\%86\%D1\%8B\%D0\%B3\%D0\%B0\%D0\%BD\%D1\%81\%D0\%BA $\%$ D0\%BE\%D0\%B5-\%D1\%81\%D1\%87\%D0\%B0\%D1\%81\%D1\%82\%D1\%8C\%D0\%B5/).

10. «Известный певеи, солист народной вокальной группь “Эрирей” Хабас Бечелов исполнил а капелла песню о родном крае» (http://kbpravda.ru/node/17165).

11. «B этот раз было сложно, много сильных соперников приехало. Особенно якуты - родоначальники вида спорта» (http://www.ogirk.ru/news/2017-0628/sportivnye-yordy.html).

12. «Рузанна Туко подверглась критике за наруиение черкесских традиций» (http:/ www.kavkaz-uzel.eu/articles/305243/).

13. «Председатель уиалинского Курултая башкир Зиля Рахматуллина» (http://www.gumilev-center.ru/istinnyjj-bashkir-znaet-tri-yazyka-i-vsegda-pri-dengakhkodeks-bashkir-sostavili-v-bashkortostane/).

14. «На Советской площади торжествовал “хоровод культур”: ярмарка народных ремесел, фестиваль ансамблей и национальной кухни» (http://vsar.ru/17238_petr_tultaev_v_drujbe_narodov__edinstvo_rossii).

15. «С 30 июня по 2 июля 2017 года в Республике Башкортостан будет проходить Открытый межнациональньй форум "Баикирская молодежь приглашает друзей"» (http://samddn.ru/novosti/novosti/zavtra-startuet-otkrytyy-mezhnatsionalnyy-forumbashkirskaya-molodezh-priglashaet-druzey/).

16. «....театр под руководством Армена Джигарханяна» (https://www.dni.ru/ showbiz/2017/6/29/373395.html).

17. «...инууи Муса Евлоев ... Ситтается, ито лииь травма не позволила этому бориу завоевать путевку на Олимпиаду-2016» (https://ulpressa.ru/2017/06/30/borotsya-i-iskat/).

18. «Командир атомной подводной лодки, капитан 1 ранга в отставке, а ныне поэт, а также уиитель истории, ветеран Афганистана, узбек Анвар Канантаров» 
(http://in-reutov.ru/novosti/tradicii/v-reutove-prazdnik-musulman-proshel-v-voskresene-v-religioznom-obshchestve-gineyni-podmoskove).

19. «Сайгдгусейн Магомедов (авареи) является неоднократным претендентом на пост главы республики» ( http://riaderbent.ru/1-iyulya-ocherednoj-politicheskij-rubezhdlya-dagestana.html).

20. «Проведение этнокультурных лагерей для детей из числа российских немиев Центрального и Северо-Западного регионов России» (http://gov.cap.ru/ info.aspx?gov_id=601\&id=3609789).

21. «К съемкам короткометражного художественного фильма “Аман” на ногайском языке приступят в сентябре» (http://nazaccent.ru/content/24547-film-na-nogajskomyazyke-o-detyah.html).

Хапцова Алена Александровна - магистр психологии, аспирант, Бременская международная аспирантская школа социальных наук, Университет Бремена и Университет Якобс в Бремене.

Сфера научных интересов: медиапсихология, информационное поведение, индивидуальные ценности.

Контакты: khaptsova@bigsss-bremen.de

Клясс Мария Владимировна - магистр психологии, преподаватель английского языка, школа № 2114.

Сфера научных интересов: предубеждения, стереотипы, сексизм.

Контакты: klyassmaria@mail.ru

Чуприков Богдан Иванович - магистр психологии, стажер-исследователь, Международная научно-учебная лаборатория социокультурных исследований, Национальный исследовательский университет «Высшая школа экономики».

Сфера научных интересов: психология религии, религиозный фундаментализм, авторитаризм правого толка.

Контакты: chbi@list.ru

\title{
Three Hypotheses of Multiculturalism in Three Days: Depiction of 46 Ethnic Minorities in Russian Online-Media
}

\author{
A.A. Khaptsova ${ }^{a}$, M.V. Klyass ${ }^{b}$, B.I. Chuprikov ${ }^{c}$ \\ ${ }^{a}$ University of Bremen and Jacobs University Bremen, UNICOM-Building, Haus 9, Mary-Somerville-Str., \\ 28359 Bremen, Germany

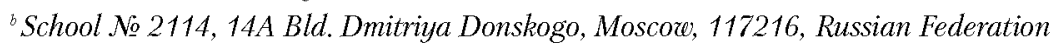 \\ 'National Research University Higher School of Economics, 20 Myasnitskaya Str., Moscore, 101000, \\ Russian Federation
}

\begin{abstract}
The issue of multiculturalism gains popularity among scholars, however very little research investigates how the media portrays this phenomenon. Research on depiction of interethnic relations in
\end{abstract}


the media is especially topical in Russia, where more than 160 ethnic groups reside. This study investigates how Russian online media portrays the 46 largest ethnic minorities living in Russia from the perspective of the three hypotheses of intercultural interaction. We designed a system of indicators of multiculturalism for the analysis of the media contents. Using content analysis, we found that online media do not cover different aspects of multiculturalism with the same frequency. In particular, most often the minorities were displayed from the point of view of the integration hypothesis, least of all from the position of the contact hypothesis. However, this observation is not valid for individual groups. The most balanced coverage was observed for the Altais and Georgians. However, when depicting the remaining 44 groups the media focused only on one of the three domains of multiculturalism. For example, the coverage of the Laks and Tajiks was focused on the integration hypothesis; the coverage of the Tuvans, Komi and Chuvash people was focused on the identity hypothesis; the coverage of the Chechens and Avars was focused on the contact hypothesis. We found that although the media tend to depict ethnic diversity positively, this tendency did not hold for certain groups: on some cases the depiction was dominated by positive contents (e.g. the Tuvans, Laks, Mordvinians), in other cases - by negative contents (the Uzbeks, Tajiks, Azerbaijanis). The potential consequences of uneven representation of ethnocultural diversity by the media for the perception of these groups in reality are discussed in this paper.

Keywords: multiculturalism, ethnic minorities, online-media, content analysis.

\section{References}

All-Russia Population Census. (2010). Vol. 4. Retrieved from http://www.gks.ru/free_doc/new_site/ perepis2010/croc/Documents/Vol4/pub-04-06.pdf (in Russian)

Berry, J. W. (2015). Intercultural relationships in plural societies. In S. Guo \& L. Wong (Eds.), Rerisiting Multiculturalism in Canada (pp. 37-49). Rotterdam/Boston/Taipei: Sense Publishers.

Berry, J. W., \& Sabatier, C. (2010). Acculturation, discrimination and adaptation among second generation immigrant youth in Montreal and Paris. International Joumal of Intercultural Relations, 34, 197-207.

Berry, J. W., \& Sam, D. L. (2014). Multicultural societies. In V. Benet-Martinez, Y.-Y. Hong (Eds.), The Oxford handbook of multicultural identity (pp. 97-117). Oxford University Press.

Bloemraad, I. (2011, September 22). The debate over multiculturalism: philosophy, politics, and policy. Migration Information Source. Retrieved from http://www.migrationpolicy.org/article/debateover-multiculturalism-philosophy-politics-and-policy

Bloemraad, I., \& Wright, M. (2014). "Utter failure" or unity out of diversity? Debating and evaluating policies of multiculturalism. International Migration Revier, 48(s1), S292-S334. doi:10.1111/imre.12135

Dandy, J., \& Pe-Pua, R. (2010). Attitudes to multiculturalism, immigration and cultural diversity: Comparison of dominant and non-dominant groups in three Australian states. International Joumal of Intercultural Relations, 34(1), 34-46. doi:10.1016/j.ijintrel.2009.10.003

European Commission: Eurobarometer 66.3. TNS OPINION \& SOCIAL, Brussels. GESIS Data Archive, Cologne, 2006. ZA4528 Data file Version 2.0.1

Galyapina, V. N., \& Lebedeva, N. M. (2016). Is multiculturalism in Russia possible? Intercultural relations in North Ossetia-Alania. Psychology in Russia: State of the Art, 9(1), 24-40. doi:10.11621/pir.2016.0102 
Gui, Y., Safdar, S., \& Berry, J. (2016). Mutual intercultural relations among university students in Canada. Frontiers: The Interdisciplinary Journal of Study Abroad, XXVII(April), 17-32.

Hillert, A., Jacobs, H., \& Müller, S. (2014). Media makes momentum. Review of Financial Studies, 27(12), 3467-3501. doi:10.1093/rfs/hhu061

Hui, B. P. H., Chen, S. X., Leung, C. M., \& Berry, J. W. (2015). Facilitating adaptation and intercultural contact: The role of integration and multicultural ideology in dominant and non-dominant groups. International Joumal of Intercultural Relations, 45, 70-84. doi:10.1016/j.ijintrel.2015.01.002

Kalin, R., \& Berry, J. W. (1995). Ethnic and civic self-identity in Canada: Analyses of 1974 and 1991 national surveys. Canadian Ethnic Studies, 27(2), 1-15.

Lebedeva, N. M., Tatarko, A. N., \& Berry, J. W. (2016). Intercultural relations in Russia and Latvia: The relationship between contact and cultural security. Psychology in Russia: State of the Art, 9(1), 41-56. doi:10.11621/pir.2016.0103

Lienemann, B. A., \& Stopp, H. T. (2013). The association between media exposure of interracial relationships and attitudes toward interracial relationships. Joumal of Applied Social Psychology, 43, E398-E415. doi:10.1111/jasp.12037

MediaScope (2017). WEB-Index: Audience of Internet projects. Results of the research: June 2017, Russia 0+. Retrieved from http://mediascope.net/services/media/media-audience/ internet/information/?arrFilter_pf $\% 5 B Y E A R \% 5 \mathrm{D}=2017 \&$ captcha_code $=0 \mathrm{c} 1 \mathrm{c} 60553 \mathrm{bee} 8 \mathrm{dd} 3 \mathrm{c} 8$ a591c9fb094ceb\&captcha_word $=44 \mathrm{~h} 38 \&$ set_filter $=\mathrm{Y}$

Melican, D. B., \& Dixon, T. L. (2015). News on the Net: credibility, selective exposure, and Racial Prejudice. Communication Research, 35(2), 151-168.

Mullainathan, S., \& Shleifer, A. (2005). Market for news. The American Economic Reriere, 95(4), 1031-1053.

Omnibus GfK. (2016, January). Internet penetration in Russia: results of 2015. Retrieved from https://www.gfk.com/fileadmin/user_upload/dyna_content/RU/Documents/Press_Releases/2 016/Internet_Usage_Russia_2015.pdf (in Russian)

Pettigrew, T. F., \& Tropp, L. R. (2006). A meta-analytic test of intergroup contact theory. Joumal of Personality and Social Psychology, 90(5), 751-783. doi:10.1037/0022-3514.90.5.751

Phinney, J.S., Jacoby, B., \& Silva, C. (2007). Positive intergroup attitudes: The role of ethnic identity. International Joumal of Behavioral Development, 31(5), 478-490.

Pietikainen, S., \& Hujanen, J. (2003). At the crossroads of ethnicity, place and identity: Representations of northern people and regions in Finnish news discourse. Media, Culture $\mathcal{E}^{\circ}$ Society, 25(2), 251-268. doi:10.1177/01634437030252007

Plaut, V. C., Garnett, F. G., Buffardi, L. E., \& Sanchez-Burks, J. (2011). "What about me?" Perceptions of exclusion and whites' reactions to multiculturalism. Joumal of Personality and Social Psychology, 101(2), 337-353. doi:10.1037/a0022832

Poindexter, P. M., Smith, L., \& Heider, D. (2003). Race and ethnicity in local television news: framing, story assignments, and source selections.Journal of Broacasting and Electronic Media, 47(4), 524536.

Public Opinion Foundation. (2016). News on the Internet: Survey of Internet users about where they read the news and what information they are interested in. Retrieved from http://fom.ru/SMI-iinternet/12491 (in Russian)

Reece, D., \& Palmgreen, P. (2000). Coming to America: need for acculturation and media use motives among indian sojourners in the US. International Joumal of Intercultural Relations, 24(6), 807-824. doi:10.1016/S0147-1767(00)00033-X 
Russian Public Opinion Research Center (2016, May). Press-vypusk № 3098. Retrieved from http:/ wciom.ru/index.php?id=236\&uid=115679 (in Russian)

Russian Public Opinion Research Center (2015, May). Press-vypusk № 2829. Retrieved from http:/ wciom.ru/index.php?id=236\&uid=115248 (in Russian)

Ryabichenko, T. A., \& Lebedeva, N. M. (2016). Assimilation or integration: Similarities and differences between acculturation attitudes of migrants from Central Asia and Russians in Central Russia. Psychology in Russia: State of the Art, 9(1), 98-111. doi:10.11621/pir.2016.0107

Soroka, S. N. (2004). No news is good news (or at least most news is bad news): assymetric responses to economic information. In European consortium for political research joint sessions of workshops (pp. 2-20). Uppsala. Retrieved from http://www.essex.ac.uk/ecpr/events/jointsessions/paperarchive/uppsala/ws15/Soroka.pdf

Stroud, N. J. (2010). Polarization and partisan selective exposure. Joumal of Communication, 60, 556-576. doi:10.1111/j.1460-2466.2010.01497.x

White, C., Duck, J. M., \& Newcombe, P. A. (2012). The impact of media reliance on the role of perceived threat in predicting tolerance of muslim cultural practice. Joumal of Applied Social Psychology, 42(12), 3051-3082. doi:10.1111/j.1559-1816.2012.00973.x

Zhao, Z., \& Postiglione, G. A. (2010). Representations of ethnic minorities in China's university media. Discourse: Studies in the Cultural Politics of Education, 31(3), 319-334. doi:10.1080/01596301003786928

Alyona A. Khaptsova - Ph.D. student, Bremen International Graduate School of Social Sciences, University of Bremen and Jacobs University Bremen.

Research area: media psychology, information behavior, individual values.

E-mail: khaptsova@bigsss-bremen.de

Maria V. Klyass - English language teacher, School № 2114.

Research area: prejudices, stereotypes, sexism.

E-mail: klyassmaria@mail.ru

Bogdan I. Chuprikov - research intern, International Laboratory for Socio-Cultural Research, National Research University Higher School of Economics.

Research area: psychology of religiosity, religious fundamentalism, right-wing authoritarianism. E-mail: chbi@list.ru 